\title{
Hepatosplenic T-Cell Lymphoma
}

National Cancer Institute

\section{Source}

National Cancer Institute. Hepatosplenic T-Cell Lymphoma. NCI Thesaurus. Code C8459.

An extranodal, mature T-cell non-Hodgkin lymphoma that originates from cytotoxic Tcells, usually of gamma/delta T-cell type. It is characterized by the presence of mediumsize neoplastic lymphocytes infiltrating the hepatic sinusoids. A similar infiltrating pattern is also present in the spleen and bone marrow that are usually involved at the time of the diagnosis. 